Article

\title{
Anti-Inflammatory Effects of 6-Methylcoumarin in LPS-Stimulated RAW 264.7 Macrophages via Regulation of MAPK and NF-кB Signaling Pathways
}

\author{
Jin-Kyu Kang ${ }^{\dagger}$, You-Chul Chung ${ }^{\dagger}$ and Chang-Gu Hyun *
}

check for updates

Citation: Kang, J.-K.; Chung, Y.-C. Hyun, C.-G. Anti-Inflammatory Effects of 6-Methylcoumarin in LPS-Stimulated RAW 264.7

Macrophages via Regulation of MAPK and NF- $\kappa B$ Signaling Pathways. Molecules 2021, 26, 5351. https://doi.org/10.3390/

molecules 26175351

Academic Editor: Maria da Graça Costa G. Miguel

Received: 12 August 2021

Accepted: 31 August 2021

Published: 2 September 2021

Publisher's Note: MDPI stays neutral with regard to jurisdictional claims in published maps and institutional affiliations.

Copyright: (c) 2021 by the authors. Licensee MDPI, Basel, Switzerland. This article is an open access article distributed under the terms and conditions of the Creative Commons Attribution (CC BY) license (https:/ / creativecommons.org/licenses/by/ $4.0 /)$.
Jeju Inside Agency \& Cosmetic Science Center, Department of Chemistry and Cosmetics, Jeju National University, Jeju 63243, Korea; wlsrbtjsrb@naver.com (J.-K.K.); jyc8385@hanmail.net (Y.-C.C.)

* Correspondence: cghyun@jejunu.ac.kr; Tel.: +82-64-754-3542

+ These authors have contributed equally to this work.

\begin{abstract}
Persistent inflammatory reactions promote mucosal damage and cause dysfunction, such as pain, swelling, seizures, and fever. Therefore, in this study, in order to explore the anti-inflammatory effect of 6-methylcoumarin (6-MC) and suggest its availability, macrophages were stimulated with lipopolysaccharide (LPS) to conduct an in vitro experiment. The effects of 6-MC on the production and levels of pro-inflammatory cytokines (interleukin (IL)-1 $\beta$, IL-6, tumor necrosis factor (TNF)- $\alpha$ ) and inflammatory mediators (nitric oxide $(\mathrm{NO})$, prostaglandin $\mathrm{E}_{2}\left(\mathrm{PGE}_{2}\right)$ ) in LPS-stimulated RAW 264.7 cells were examined. The results showed that 6-MC reduced the levels of $\mathrm{NO}$ and $\mathrm{PGE}_{2}$ without being cytotoxic. In addition, it was demonstrated that the increase in the expression of pro-inflammatory cytokines caused by LPS stimulation, was decreased in a concentration-dependent manner with 6-MC treatment. Moreover, Western blot results showed that the protein levels of inducible nitric oxide synthase (iNOS) and cyclooxygenase-2 (COX-2), which increased with LPS treatment, were decreased by 6-MC treatment. Mechanistic studies revealed that 6-MC reduced the phosphorylation of the mitogen-activated protein kinase (MAPK) family and IKB $\alpha$ in the MAPK and nuclear factor-kappa B (NF-kB) pathways, respectively. These results suggest that 6-MC is a potential therapeutic agent for inflammatory diseases that inhibits inflammation via the MAPK and NF-kB pathways.
\end{abstract}

Keywords: 6-methylcoumarin; macrophage; inflammation; NF-кB; MAPK; coumarin

\section{Introduction}

The inflammatory reaction is an essential defense mechanism that protects the body during pathogen invasion or tissue damage and can be described as an acute or chronic inflammatory reaction according to the action and period of occurrence [1,2]. In the acute inflammatory reaction, as macrophages are activated by antigens, pro-inflammatory cytokines (interleukin-1 $\beta$ (IL-1 $\beta$ ), interleukin-6 (IL-6), tumor necrosis factor- $\alpha$ (TNF- $\alpha)$ ), and inflammatory mediators (nitric oxide $(\mathrm{NO})$, prostaglandin $\mathrm{E}_{2}\left(\mathrm{PGE}_{2}\right)$ ) are secreted to remove foreign substances and are terminated through the process of tissue regeneration [3-6]. Symptoms during the inflammatory reaction include fever, swelling, and pain [7]. In this inflammatory response, macrophages are involved in host defense and homeostasis, and are activated by bacterial lipopolysaccharide (LPS), a cell wall component of Gram-negative bacteria, to express several inflammatory mediators. In the inflammatory response, macrophages receive stimuli through the surface receptor Toll-like receptor 4 (TLR4) $[8,9]$. This stimulus increases the production of pro-inflammatory cytokines (IL-1 $\beta$, IL-6, and TNF- $\alpha$ ) and inflammatory mediators (NO and PGE 2 ) through the activation of phosphorylation of transcription factors nuclear factor-kappa B (NF- $\mathrm{B}$ ) and mitogenactivated protein kinase (MAPK). Thus, these inflammatory mediators can kill bacteria or remove tumors and eventually contribute to the body's defenses [10-21]. However, it 
has been reported that pathological overexpression of these pro-inflammatory cytokines and inflammatory mediate factors may cause genetic mutations or tissue and nerve damage, resulting in fatal consequences for the body [22]. Recently, the overproduction of inflammatory mediators due to environmental pollution or increased stress has led to chronic inflammation or immune hypersensitivity reactions [23]. As a result, the incidence of several diseases such as rheumatoid arthritis, cancer, and inflammatory bowel disease is increasing [24-30]. Therefore, the regulation of the inflammatory response is very important for the maintenance of the living body, and the anti-inflammatory effects can be confirmed through the inhibitory effects on the production of inflammatory mediators such as $\mathrm{NO}, \mathrm{PGE}_{2}$, and cytokines generated from the inflammatory reaction. Coumarin is synthesized from shikimic acid pathways in bacteria, fungi, and plants and its derivatives include umbelliferone, esculetin, herniarin, psoralen, and imperatorin. Recent studies have reported that these coumarin derivatives have biological activities, including antioxidant, anti-inflammatory, antibacterial, antiviral, and anti-cancer functions. In addition, various substituents in the coumarin skeleton may exhibit different biological activities because of their structural differences, which may increase or decrease their effects [31-36].

During our screening process to find functional substances of skin inflammation and melanogenesis from coumarin and its derivatives, it was observed that several coumarin derivatives have bioactivities on inflammation and melanogenesis. Based on these results, we reported that 6,7-dihydroxy-4-methylcoumarin inhibited inflammation via MAPK signaling pathways [37]. In addition, we identified that 7,8-dimethoxycoumarin attenuates inflammation via NF-KB and MAPK signaling pathways [38]. Furthermore, it was reported that 8-methoxycoumarin increased melanogenesis via MAPK pathways [39]. As an extension of this study, we screened several coumarins, which have similar structure, to identify the structural features involved in the bioactivities of this class of molecules.

In this study, we observed that among the compounds screened, four coumarin derivatives, (a) 6-methylcoumarin (6-MC), (b) 7-methylcoumarin (7-MC), (c) 4-hydroxy-6methylcoumarin (4H-6-MC), and (d) 4-hydroxy-7-methylcoumarin (4H-7-MC), which have similar structures (Figure 1), exhibit distinct potency derived of their structural differences. In addition, the anti-inflammatory potential of each coumarin was evaluated based on their capacity to reduce cellular NO levels, the most promising coumarin being selected, and a mechanistic study conducted.<smiles>Cc1ccc2oc(=O)ccc2c1</smiles>

(a)<smiles>Cc1ccc2oc(=O)cc(O)c2c1</smiles>

(c)<smiles>Cc1ccc2ccc(=O)oc2c1</smiles>

(b)<smiles>Cc1ccc2c(O)cc(=O)oc2c1</smiles>

(d)

Figure 1. The chemical structure of (a) 6-methylcoumarin (6-MC), (b) 7-methylcoumarin (7-MC), (c) 4-hydroxy-6-methylcoumarin (4H-6-MC), and (d) 4-hydroxy-7-methylcoumarin (4H-7-MC).

\section{Results}

\subsection{Effect of Coumarin Derivatives on the Proliferation and NO Production of RAW 264.7 Cells}

To investigate the cytotoxicity of coumarin derivatives against RAW 264.7 cells, cell viability was investigated using the 3-(4,5-dimethylthiazol-2-yl)-2,5-diphenyltetrazolium bromide (MTT) assay. The cells were treated with coumarin derivatives $(200,300,400$, and $500 \mu \mathrm{M})$ and LPS $(1 \mu \mathrm{g} / \mathrm{mL})$ and incubated for $24 \mathrm{~h}$ to measure absorbance. As a result, there were no significant differences between the untreated control and coumarin 
derivatives-treated group in RAW 264.7 cells (Figure 2). Therefore, coumarin derivatives were considered to have no cytotoxicity at the treated concentrations, and further studies were conducted using the following concentrations: 200, 300, 400, and $500 \mu \mathrm{M}$.

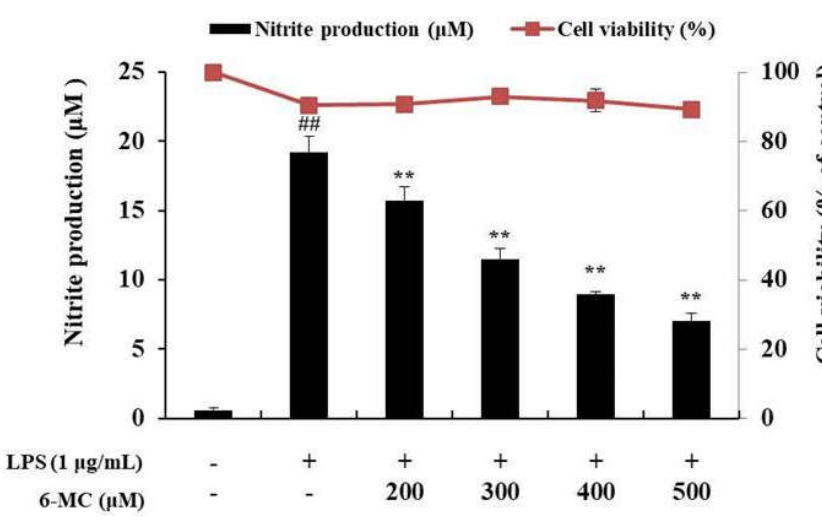

(a)

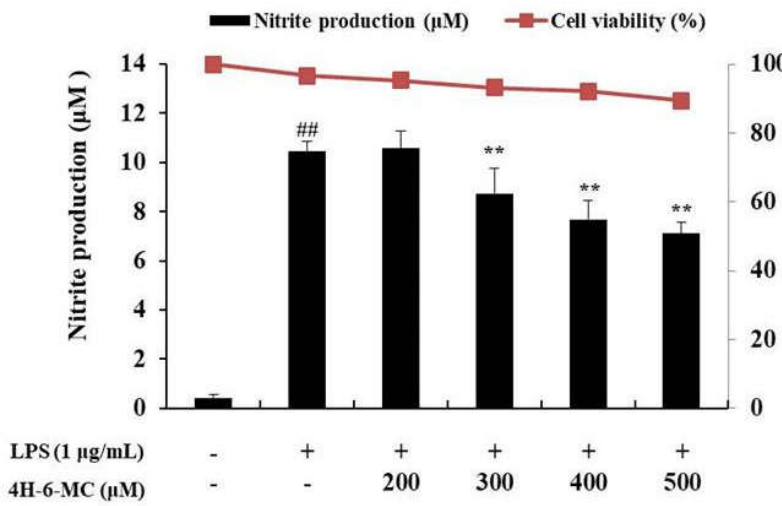

(c)

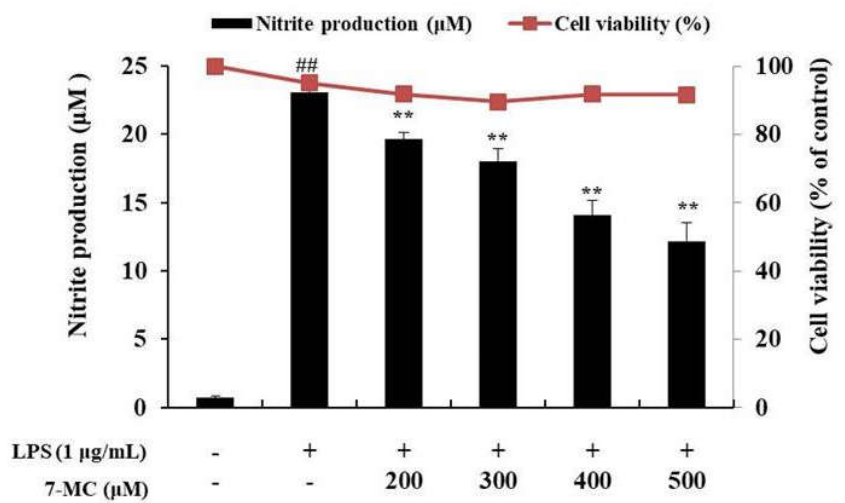

(b)

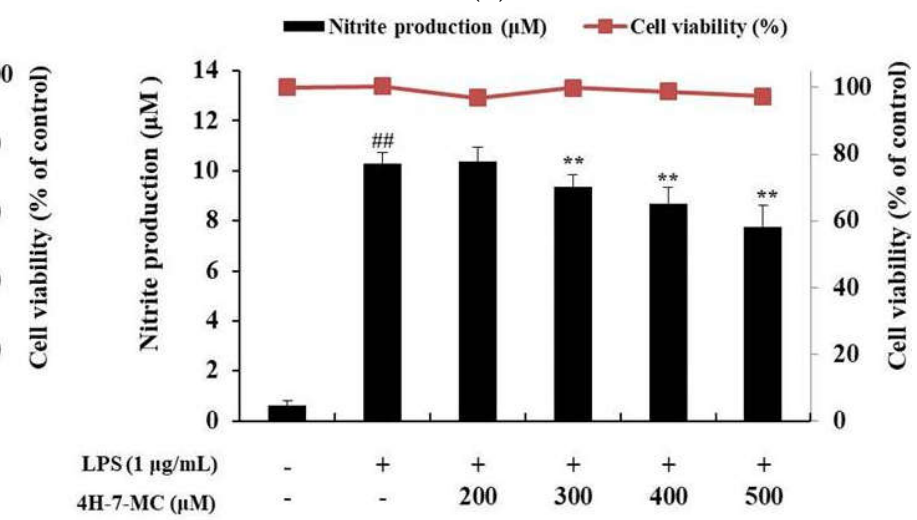

(d)

Figure 2. Effect of coumarin derivatives on nitric oxide production in LPS-stimulated RAW 264.7 cells. The cells were stimulated with $1 \mu \mathrm{g} / \mathrm{mL}$ of LPS only or with LPS plus various concentrations of coumarin derivatives for $24 \mathrm{~h}$. Cell viability and NO production of LPS-induced RAW 264.7 cells subjected to (a) 6-methylcoumarin (6-MC), (b) 7-methylcoumarin (7-MC), (c) 4-hydroxy-6-methylcoumarin (4H-6-MC), and (d) 4-hydroxy-7-methylcoumarin (4H-7-MC) treatment was measured using MTT and Griess reagents, respectively. The results are presented as the mean \pm SD from three independent experiments. \#\# $p<0.01$ versus untreated control group. ${ }^{* *} p<0.01$ versus LPS alone.

To examine the effect of coumarin derivatives on NO production, cells were pretreated with each coumarin derivative $(200,300,400$, and $500 \mu \mathrm{M})$ for $1 \mathrm{~h}$ and then stimulated for $24 \mathrm{~h}$ with LPS $(1 \mu \mathrm{g} / \mathrm{mL})$. The cells treated with LPS alone markedly induced NO production compared to the untreated control cells. However, NO production was significantly decreased by coumarin treatment in a concentration-dependent manner. In particular, $500 \mu \mathrm{M}$, which was the highest concentration tested, decreased the NO production level by $63.5 \%$ for $6-\mathrm{MC}, 47.3 \%$ for $7-\mathrm{MC}, 32.1 \%$ for $4 \mathrm{H}-6-\mathrm{MC}$, and $26.4 \%$ for $4 \mathrm{H}-7-\mathrm{MC}$, compared with the LPS alone-treated group (Figure $2 \mathrm{a}-\mathrm{d},{ }^{* *} p<0.01$ ).

\subsection{Effect of Coumarin Derivatives on Proliferation and Melanin Contents of B16F10 Cells}

Several studies have showed that the substances with anti-inflammatory activity are also involved in melanogenesis [21,38-42]. Therefore, to check whether these coumarin derivatives also affect the melanogenesis, MTT assay and melanin contents test were performed using B16F10 murine melanoma cells. The cells were treated with coumarin derivatives (150, 200, 250, and $300 \mu \mathrm{M})$ and incubated for $72 \mathrm{~h}$ to measure absorbance. $\alpha$-melanocyte-stimulating hormone (MSH) $(100 \mathrm{nM})$ was used as the positive control. The MTT assay result showed that there were no significant differences between the 
untreated control and coumarin derivatives-treated group at indicated concentrations $(150,200$, and $250 \mu \mathrm{M})$ in B16F10 cells. Therefore, coumarin derivatives were considered to have no cytotoxicity at concentrations under $250 \mu \mathrm{M}$. The melanin content test was conducted using the following concentrations: 100, 150, 200, and $250 \mu \mathrm{M}$ (Figure 3). The result of melanin contents test showed that, the cells treated with 6-MC showed an increase in melanin content compared to that in the untreated control cells (Figure 3a). However, there were no significant differences between the untreated control cells and other coumarin derivative-treated groups (Figure $3 \mathrm{~b}-\mathrm{d}$ ). Based on NO production and melanin contents results, it can be confirmed that the bioactivity of 6-MC is better than that of other coumarin derivatives. Therefore, further experiments were performed to investigate the anti-inflammatory effects of 6-MC.

\subsection{Effect of 6-MC on $P G E_{2}$ and Pro-Inflammatory Cytokines Expression}

To examine the effect of 6-MC on the expression of $\mathrm{PGE}_{2}$ and pro-inflammatory cytokines such as TNF- $\alpha$, IL-6, and IL-1 $\beta$, LPS-stimulated RAW 264.7 cells were treated with various concentrations. The expression levels of cytokines were measured using ELISA kits. The cells treated with LPS alone showed a marked increase in inflammatory cytokine levels compared to those in the untreated control cells. However, the levels of PGE 2 , TNF- $\alpha$, IL-6, and IL-1 $\beta$ were significantly decreased in 6-MC-treated cells in a concentration-dependent manner. In particular, $500 \mu \mathrm{M}$, which was the highest treatment concentration, markedly decreased $\mathrm{PGE}_{2}, \mathrm{TNF}-\alpha$, IL- 6 , and IL- $1 \beta$ expression levels by $53.2 \%, 32.8 \%, 73.1 \%$, and $80.6 \%$, respectively, compared with the LPS alone-stimulated group (Figure $4 \mathrm{a}-\mathrm{d},{ }^{* *} p<0.01$ ).

\subsection{Measurement of iNOS and COX-2 Protein Expression}

Recent studies have reported that $\mathrm{NO}$ and $\mathrm{PGE}_{2}$ production is regulated by iNOS and COX-2 protein expression $[43,44]$. Therefore, the expression of iNOS and COX-2 was confirmed by Western blotting to determine whether the expression of inflammatory mediators is related to the expression of iNOS and COX-2. As shown in Figure 4a, iNOS expression was increased 3.85-fold in cells treated with LPS alone compared to that in untreated control cells. However, it was decreased by $33.8 \%, 54.52 \%, 70.79 \%$, and $92.79 \%$ at 6-MC treatment concentrations of 200,300, 400, and $500 \mu \mathrm{M}$, respectively (Figure 5a, ** $p<0.01)$. In addition, COX-2 expression was increased by 35.7 -fold in the LPS alonetreated group compared with untreated control cells, and it was decreased by $40.8 \%, 62.7 \%$, $78.2 \%$, and $95.78 \%$, respectively (Figure $\left.5 \mathrm{~b},{ }^{* *} p<0.01\right)$, in the presence of $6-\mathrm{MC}(200,300$, 400 , and $500 \mu \mathrm{M}$ ) (Figure $4 \mathrm{~b}$ ). Therefore, the results suggest that 6-MC suppresses the production of $\mathrm{NO}$ and $\mathrm{PGE}_{2}$, which are inflammatory mediators, through inhibition of iNOS and COX-2 protein expression, respectively.

\subsection{Effect of 6-MC on the Phosphorylation of MAPK}

It has been reported that LPS stimulates TLR4 on the surface of macrophages to induce phosphorylation of MAPK (extracellular signal regulated kinase; ERK, c-Jun Nterminal kinase; JNK, p38) to activate a cell signaling pathway and increase the expression of various inflammatory cytokines [11-13]. Therefore, Western blotting was performed to confirm whether the inhibitory effect of 6-MC on inflammatory cytokine expression was due to the inhibition of MAPK phosphorylation. As shown in Figure 6, there was significant phosphorylation of ERK (4.1-fold), JNK (3.1-fold), and p38 (2.5-fold) in cells treated with LPS alone compared to untreated control cells. It was also confirmed that LPS-stimulated phosphorylation of ERK, JNK, and p38 was attenuated by 6-MC treatment in a concentration-dependent manner. In particular, $500 \mu \mathrm{M}$, which was the highest treatment concentration, markedly decreased ERK, JNK, and p38 phosphorylation levels by $38.9 \%, 53.8 \%$, and $59.7 \%$, respectively, compared with the LPS alone-stimulated group (Figure $6 \mathrm{~b}-\mathrm{d},{ }^{* *} p<0.01$ ). Thus, the results suggest that $6-\mathrm{MC}$ suppresses inflammatory cytokine expression by blocking MAPK phosphorylation. 

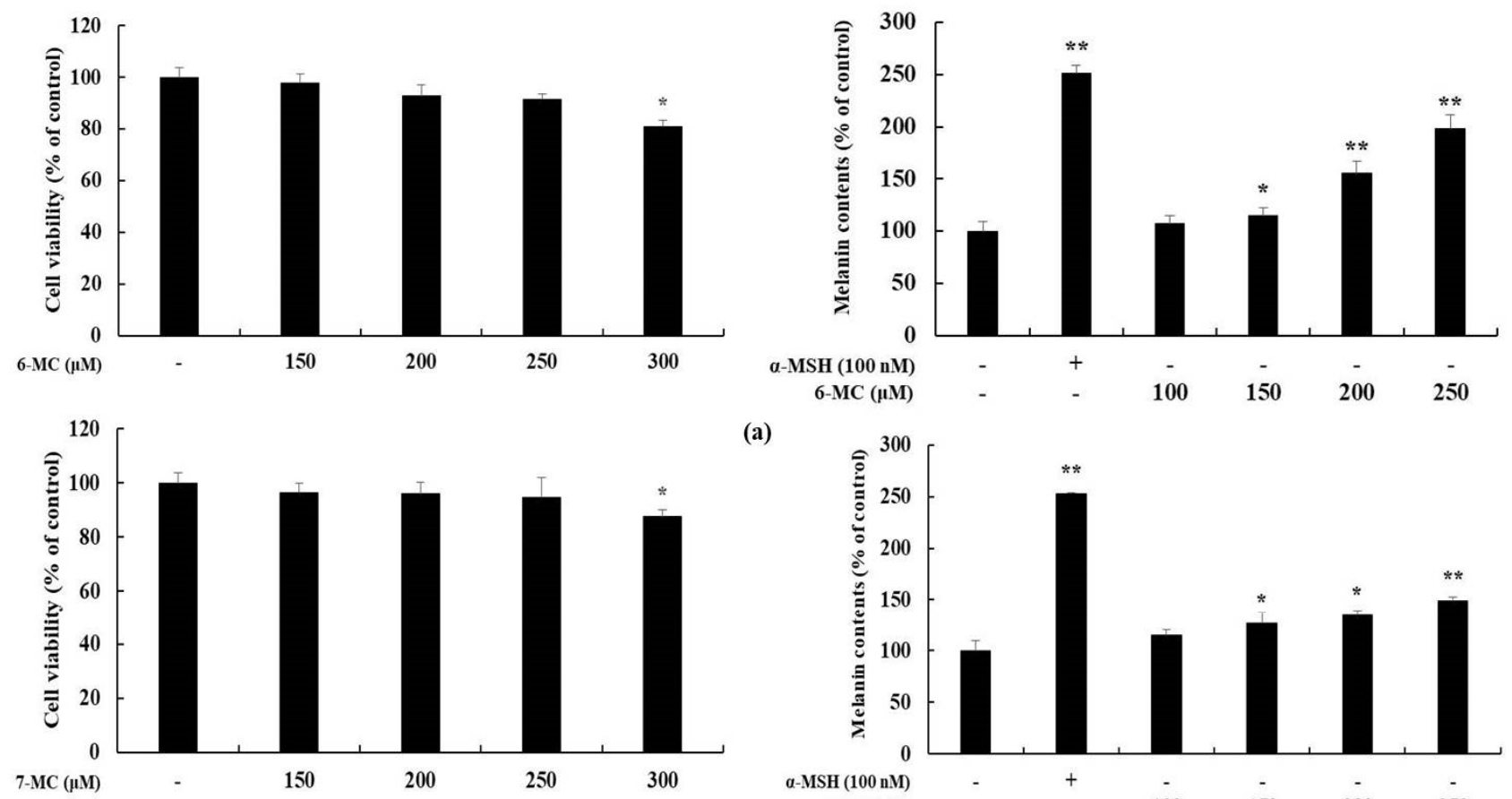

(a)

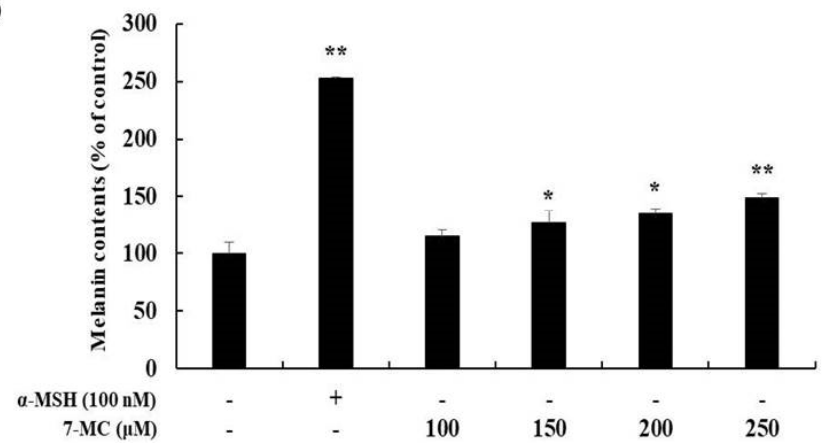

(b)
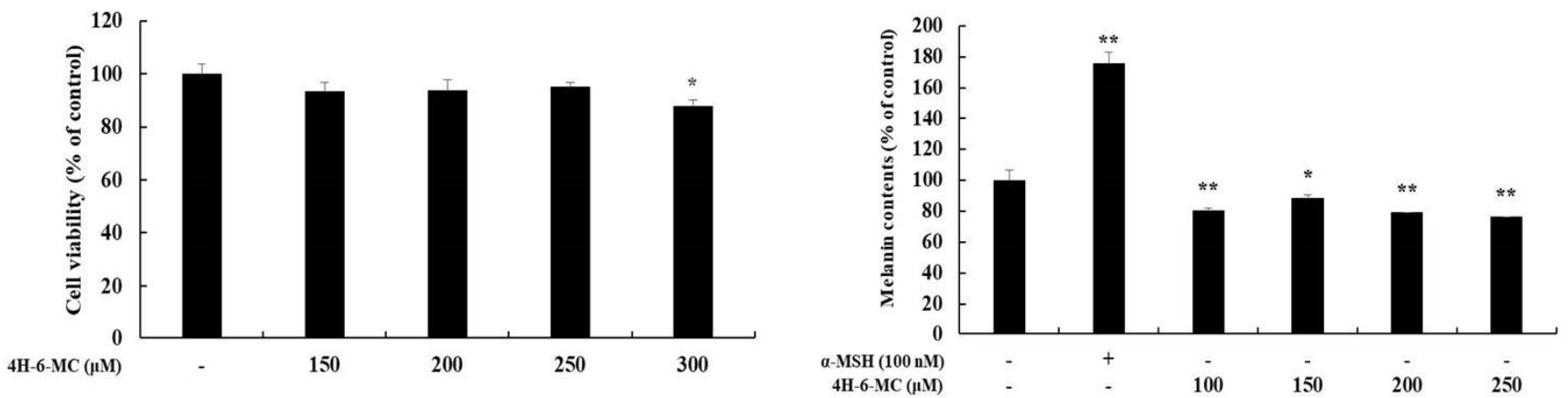

(c)
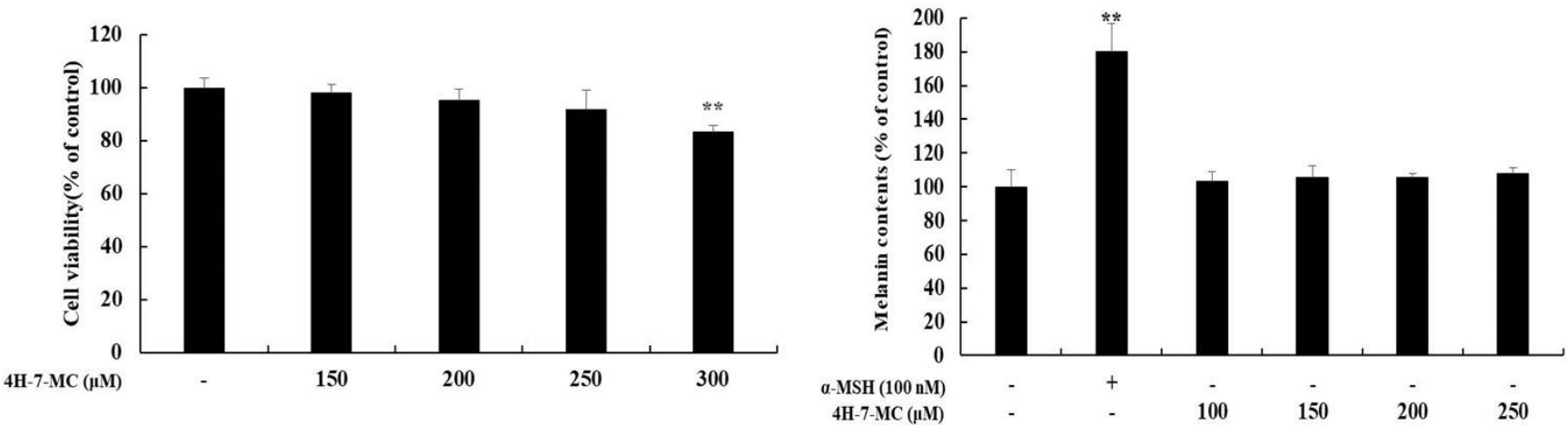

(d)

Figure 3. Effect of coumarin derivatives on proliferation and melanin contents in B16F10 cells. The cells were treated with various concentrations of coumarin derivatives for $72 \mathrm{~h}$. $\alpha$-MSH was used as the positive control. Proliferation and melanin contents of cells subjected to (a) 6-methylcoumarin (6-MC), (b) 7-methylcoumarin (7-MC), (c) 4-hydroxy-6-methylcoumarin (4H-6-MC), and (d) 4-hydroxy-7-methylcoumarin (4H-7-MC) treatment were expressed as percentages compared to the untreated control cells. The results are presented as the mean $\pm \mathrm{SD}$ from three independent experiments. ${ }^{*} p<0.05$, ${ }^{* *} p<0.01$ versus untreated control cells. 


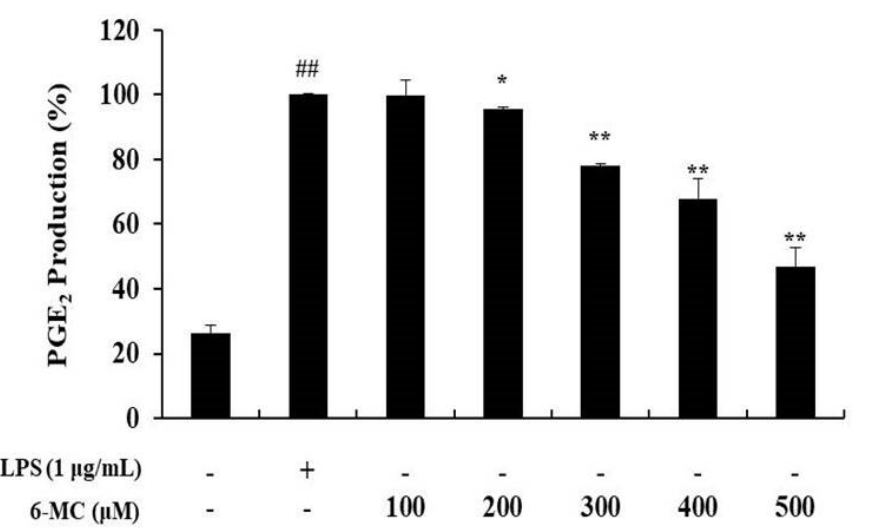

(a)

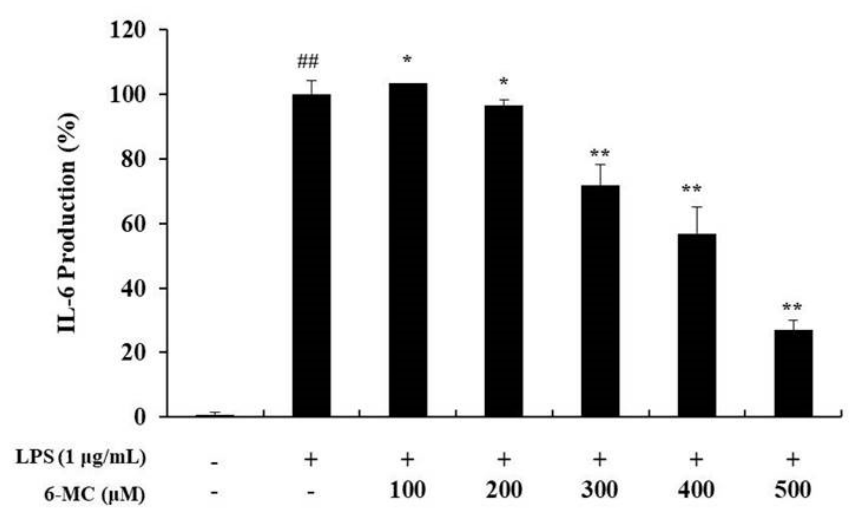

(c)

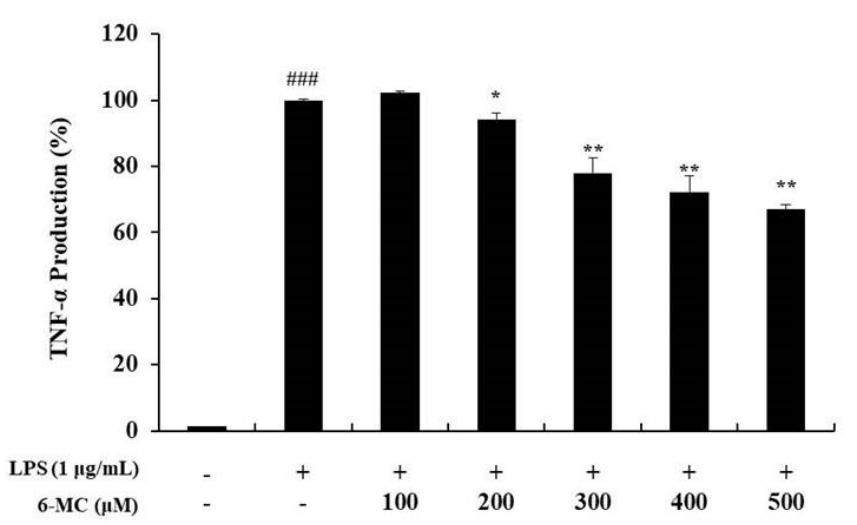

(b)

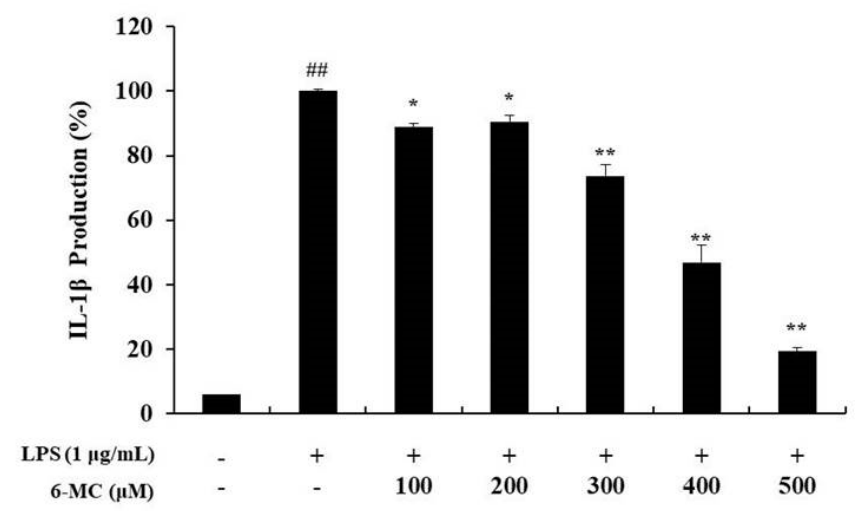

(d)

Figure 4. Effect of 6-MC on the production of $\mathrm{PGE}_{2}$ and pro-inflammatory cytokines in LPS-induced RAW 264.7 cells. Cells were pretreated with 6-MC for $1 \mathrm{~h}$ and subsequently stimulated for $24 \mathrm{~h}$ with LPS. (a) PGE 2 , (b) TNF- $\alpha$, (c) IL-6, and (d) IL-1 $\beta$ production was determined by ELISA. The results are presented as the mean \pm SD from three independent experiments. \#\# $p<0.01$ vs. untreated control group. ${ }^{*} p<0.05,{ }^{* *} p<0.01$ vs. group treated with LPS alone.

\subsection{Effect of 6-MC on the NF- $\mathrm{kB}$ Signaling Pathway}

A previous study reported that in LPS-stimulated macrophages, IкB- $\alpha$ is phosphorylated by I $\mathrm{\kappa B}-\alpha$ kinase and subsequently ubiquitinated. Consequently, I $\kappa \mathrm{B}-\alpha$ is released from the NF- $\mathrm{kB}$ complex and undergoes degradation. In addition, phosphorylated NF- $\mathrm{kB}$ (p50 and p65) is translocated to the nucleus, increasing the production of inflammatory cytokines and proteins, including iNOS and COX-2 [45]. To investigate the molecular mechanism of 6-MC-mediated inhibition of inflammatory cytokine expression, NF- $\mathrm{kB}$ pathway activity was investigated using a Western blot assay. As shown in Figure 7, LPS stimulation of cells decreased IкB- $\alpha$ expression. However, it was significantly increased by 6-MC $(300,400,500 \mu \mathrm{M})$ treatment, with a $43.4 \%$ increase at $500 \mu \mathrm{M}$ (Figure $7 \mathrm{~b},{ }^{* *} p<0.01$ ). Phosphorylation of IкB- $\alpha$ was markedly induced by LPS treatment, but it was decreased by 6 -MC treatment, with a $35.8 \%$ decrease at $500 \mu \mathrm{M}$ (Figure $7 \mathrm{c},{ }^{* *} p<0.01$ ). Next, we confirmed the translocation of NF- $\mathrm{kB} / \mathrm{p} 65$ from the cytoplasm to the nucleus. In the cytoplasm, p65 expression in cells treated with LPS was decreased compared to that in untreated control cells, while treatment with 6-MC significantly prevented the inhibition of p65 expression in a concentration-dependent manner. In the nucleus, the expression of p65 was increased in cells treated with LPS compared to untreated control cells, but it was inhibited by 6-MC treatment (Figure 8). These results suggest that 6-MC prevents IKB- $\alpha$ degradation and NF- $\mathrm{KB}$ nuclear translocation, thereby impeding inflammation. 


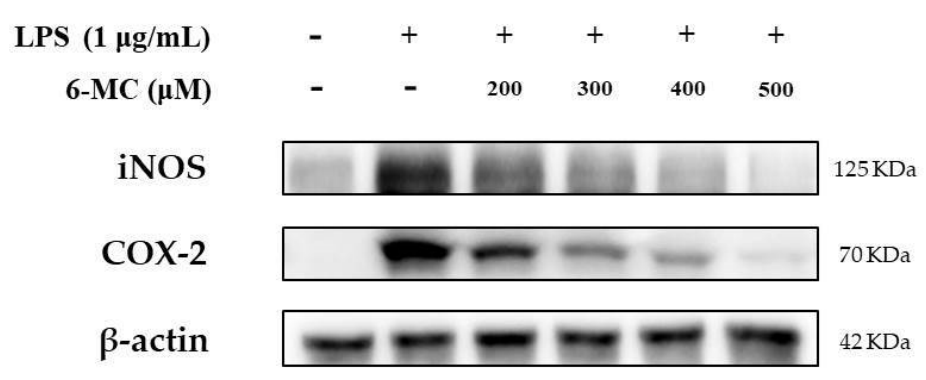

(a)

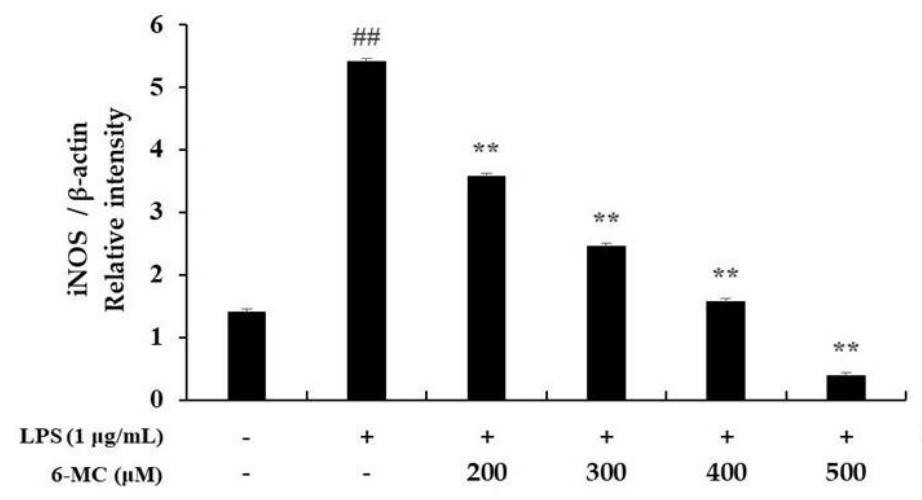

(b)

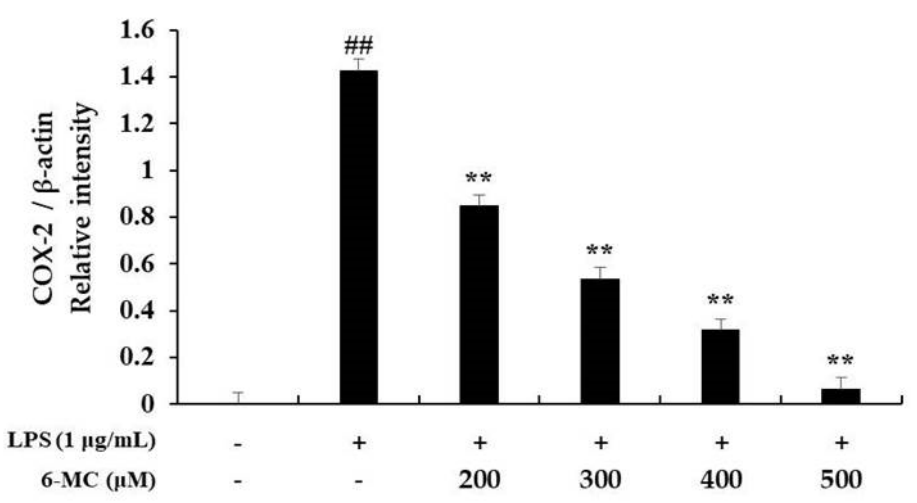

(c)

Figure 5. Effect of 6-MC on the protein expression level of iNOS and COX-2 in LPS-induced RAW 264.7 cells. (a) Result of Western blotting, and protein levels of (b) iNOS and (c) COX-2. Lysates were prepared from cells pretreated with 6-MC (200, $300,400$, and $500 \mu \mathrm{M})$ for $1 \mathrm{~h}$ and then treated with LPS $(1 \mu \mathrm{g} / \mathrm{mL})$ for $18 \mathrm{~h}$. $\beta$-actin was used as a loading control. Total cellular proteins were separated using SDS-PAGE, transferred to PVDF membranes, and detected using specific antibodies against iNOS, COX-2, and $\beta$-actin. The results in the graphs are presented as the mean \pm SD from three independent measurements using the ImageJ program. \#\# $p<0.01$ vs. untreated control group. ${ }^{* *} p<0.01$ versus group treated with LPS alone. 


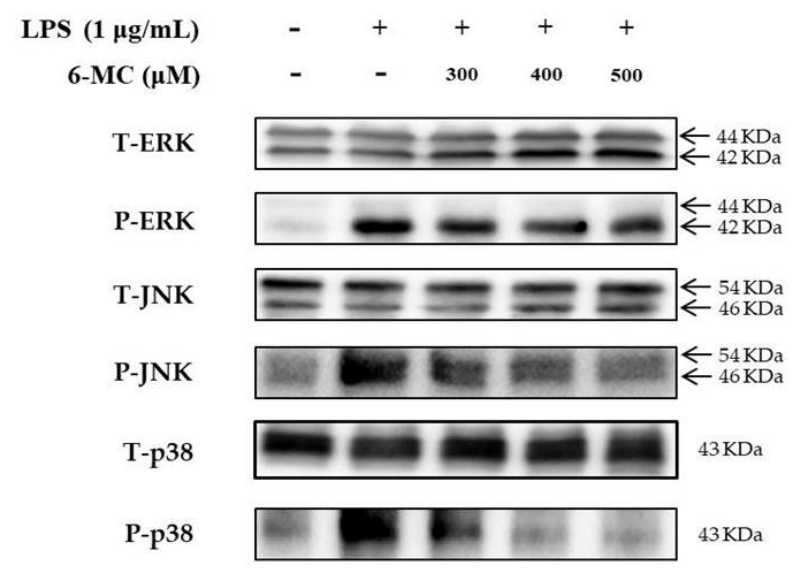

(a)

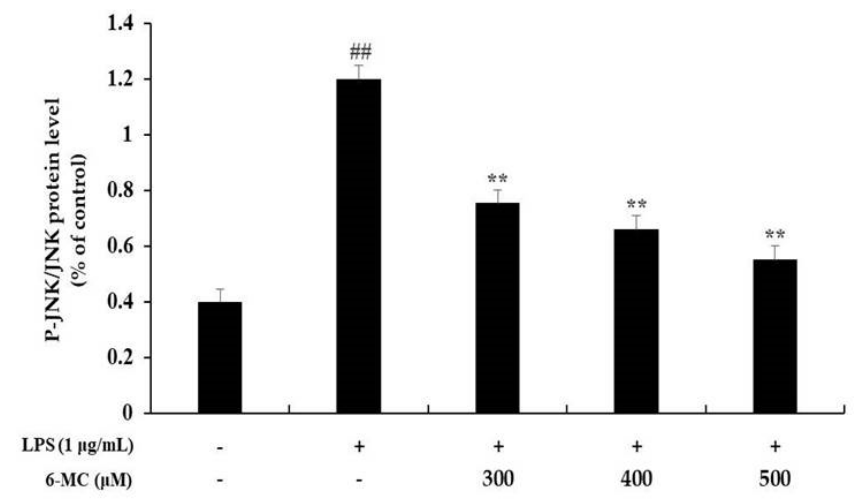

(c)

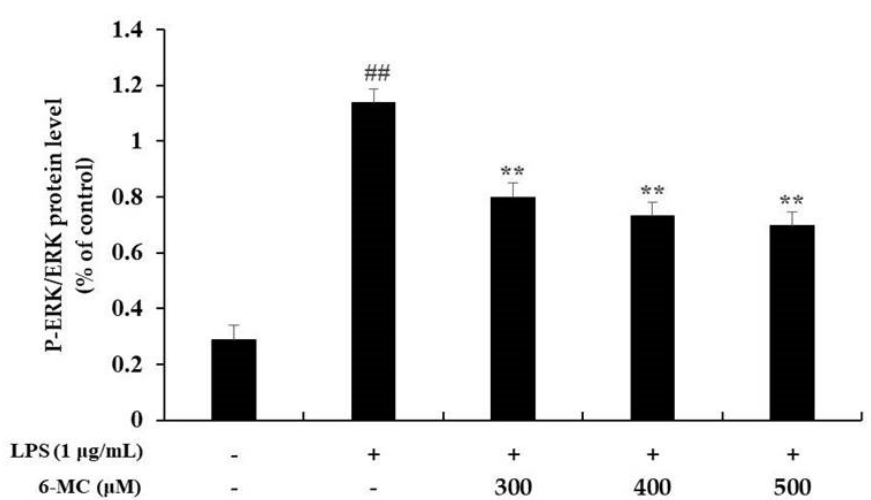

(b)

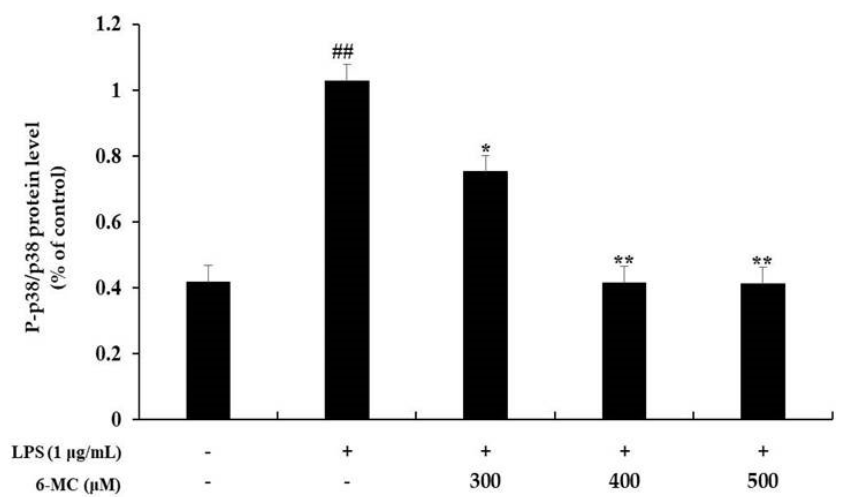

(d)

Figure 6. Effect of 6-MC on phosphorylation level of MAPK in LPS-induced RAW 264.7 cells. (a) Result of Western blotting, and protein levels of (b) P-ERK/ERK, (c) P-JNK/JNK, and (d) P-p38/p38. Lysates were prepared from cells pretreated with 6-MC $(300,400$, and $500 \mu \mathrm{M})$ for $1 \mathrm{~h}$ and then treated with LPS $(1 \mu \mathrm{g} / \mathrm{mL})$ for $15 \mathrm{~min}$. $\beta$-actin was used as a loading control. Total cellular proteins were separated using SDS-PAGE, transferred to PVDF membranes, and detected using specific antibodies against phospho-ERK, T-ERK, phospho-JNK, T-JNK, phospho-p38, and T-p38. P: phosphorylated, T: total. The results in the graphs are presented as the mean \pm SD from three independent measurements using the ImageJ program. \#\# $p<0.01$ vs. untreated control group. ${ }^{*} p<0.05,{ }^{* *} p<0.01$ versus group treated with LPS alone. 


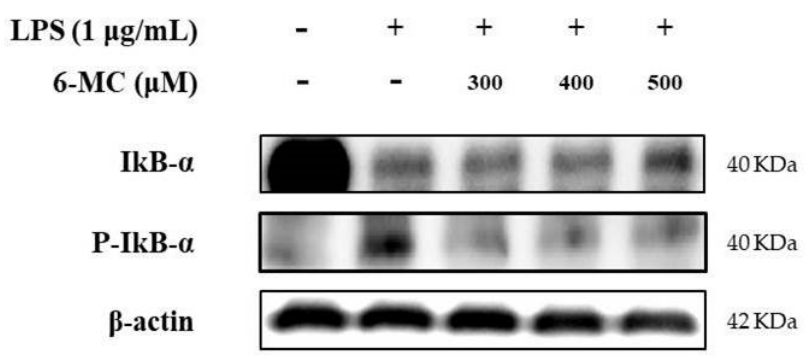

(a)

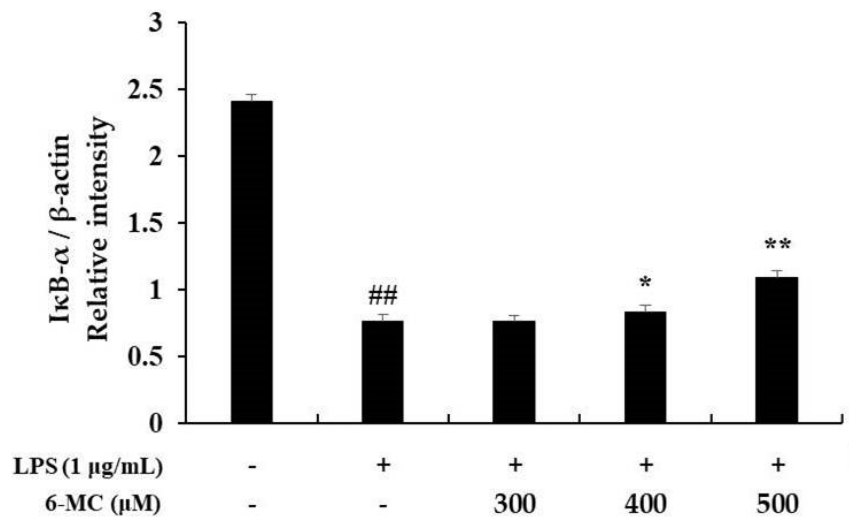

(b)

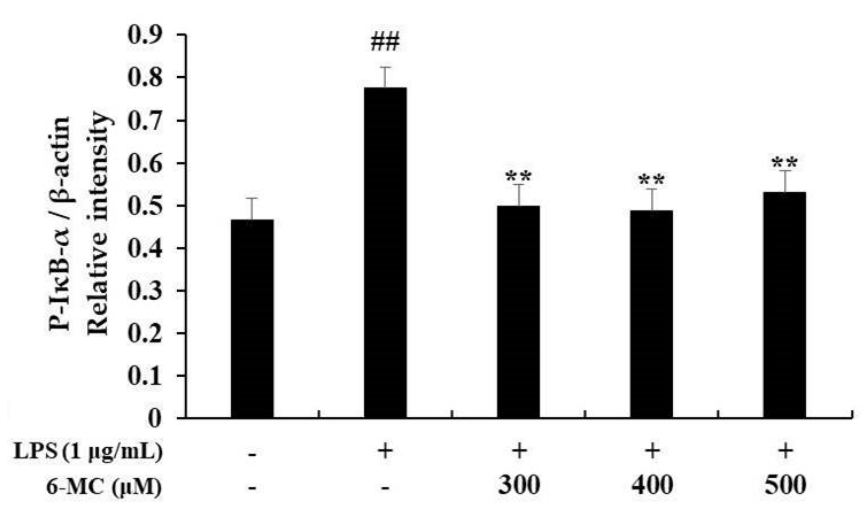

(c)

Figure 7. Effect of 6-MC on the protein expression level of P-IкB- $\alpha$ and IкB- $\alpha$ in LPS-induced RAW 264.7 cells. (a) Result of Western blotting, and protein level of (b) I $\kappa$ B- $\alpha$ and (c) P-I $\kappa$ B- $\alpha$. Lysates were prepared from cells pretreated with 6-MC $(300,400$, and $500 \mu \mathrm{M})$ for $1 \mathrm{~h}$ and then treated with LPS $(1 \mu \mathrm{g} / \mathrm{mL})$ for $20 \mathrm{~min}$. $\beta$-actin was used as a loading control. Total cellular proteins were separated using SDS-PAGE, transferred to PVDF membranes, and detected using specific antibodies against phospho-IкB- $\alpha$, I $\mathrm{KB}-\alpha$, and $\beta$-actin. The results in the graphs are presented as the mean \pm SD from three independent measurements using the ImageJ program. \#\# $p<0.01$ vs. untreated control group. ${ }^{*} p<0.05$, ** $p<0.01$ versus group treated with LPS alone. 


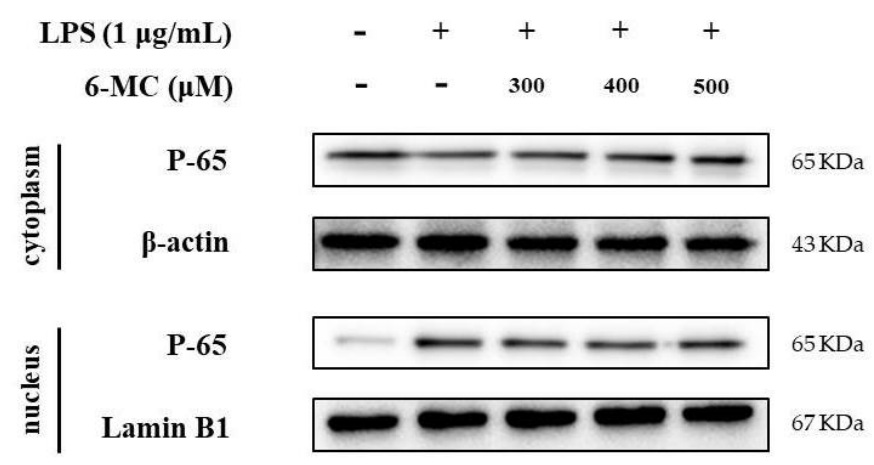

(a)

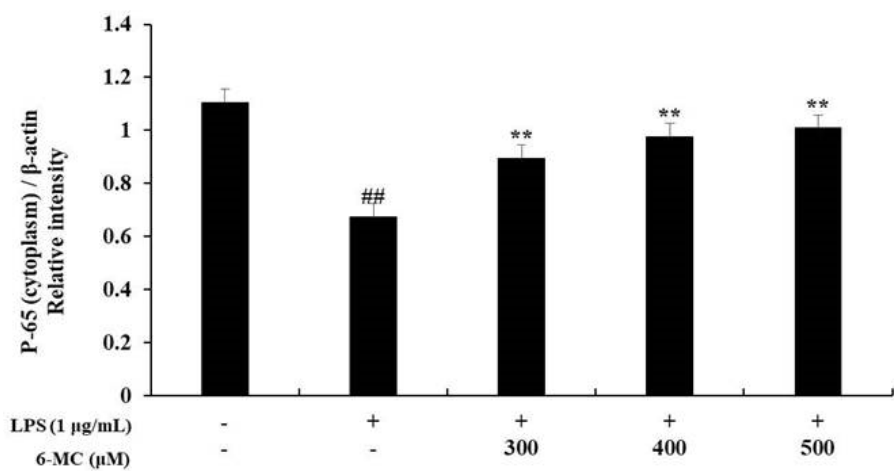

(b)

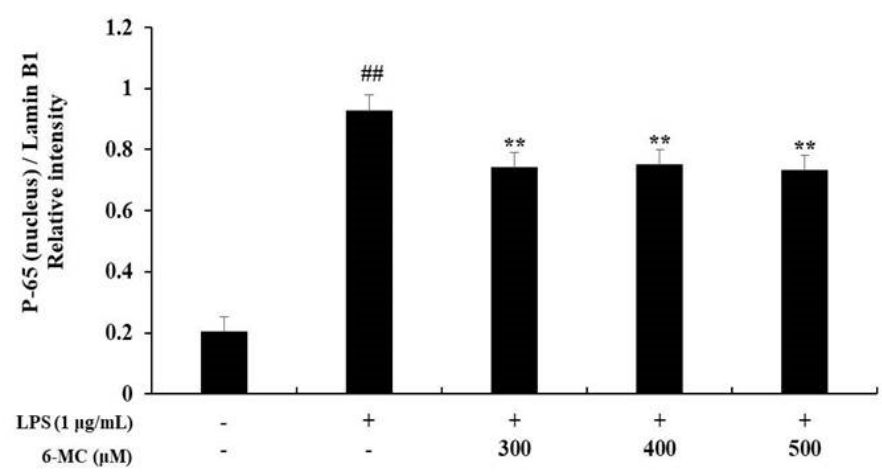

(c)

Figure 8. Effect of 6-MC on the protein expression level of NF-kB (P-65; cytoplasm) and (P-65; nucleus) in LPS-induced RAW 264.7 cells. (a) Result of Western blotting, and protein level of (b) P-65 (cytoplasm) and (c) P-65 (nucleus). Lysates were prepared from cells pretreated with 6-MC $(300,400$, and $500 \mu \mathrm{M})$ for $1 \mathrm{~h}$ and then treated with LPS $(1 \mu \mathrm{g} / \mathrm{mL})$ for 15 min. $\beta$-actin and Lamin B1 were used as a loading control. Total cellular proteins were separated using SDS-PAGE, transferred to PVDF membranes, and detected using specific antibodies against NF- $\mathrm{B} / \mathrm{P}-65$, Lamin B1, and $\beta$-actin. The results in the graphs are presented as the mean \pm SD from three independent measurements using the ImageJ program. \#\# $p<0.01$ vs. untreated control group. ${ }^{* *} p<0.01$ versus group treated with LPS alone.

\section{Discussion}

Various coumarins and their derivatives exist in natural products and have been extensively studied for their biological activities, including antioxidant, anti-inflammatory, antibacterial, antiviral, and anti-cancer functions [34-36]. In addition, various substituents in the coumarin skeleton may exhibit different biological activities owing to their structural differences [31]. Therefore, the comparison of biological activity based on structural differences would be useful for predicting effective functional substances. In this study, we selected coumarin derivatives with similar structures and compared their NO production inhibitory activities. By comparing 6-methylcoumarin and 7-methylcoumarin, we found that the NO inhibitory activity of 6-methylcoumarin was better. Interestingly, when a hydroxyl group was attached to the 4-position of 6-methylcoumarin (4H-6-MC) and 7-methylcoumarin (4H-7-MC), the NO inhibitory activity of coumarin was decreased (Figures 1 and 2). To check whether this phenomenon also affects the activity of other cells, a melanin content test was performed using B16F10 cells. As a result, it was confirmed that melanin production increased in a concentration-dependent manner in 6-MC, which had the best NO production inhibitory activity (Figure 3a), and it was also confirmed that melanin content slightly increased in 7-MC (Figure 3b). However, it was confirmed that when a hydroxyl group was attached to the 4-position of 6-methylcoumarin (4H-6-MC) and 7-methylcoumarin (4H-7-MC), it is slightly decreased in melanin contents (Figure 3c) or it did not affect melanogenesis (Figure 3d). Therefore, it is considered that the biological 
activity of coumarin is affected by the hydroxyl group at position 4 in the coumarin skeleton. Based on these results, we conducted an anti-inflammatory study using 6-MC, which has the best biological activity in NO inhibition and melanin activation.

Recent studies reported that coumarin and its derivatives related to anti-inflammatory activities. It has reported that auraptene, a natural bioactive monoterpene coumarin ether, inhibits inflammation via the p38 MAPK signaling pathway in RAW 264.7 cells [46]. In addition, it was confirmed that esculin, a coumarin glucoside, exhibited anti-inflammatory activities in vivo and regulated TNF- $\alpha$ and IL-6 production in LPS-stimulated mouse peritoneal macrophages in vitro through the MAPK pathway [47]. Furthermore, it was studied that various coumarin derivatives such as 7,8-dimethoxycoumarin, 6,7-dihydroxy4-methylcoumarin, and 4-hydroxy-7-methoxycoumarin have anti-inflammatory activity via the MAPK and NF- $\mathrm{kB}$ signaling pathways [37,38,48]. Therefore, in this study, we focused on the anti-inflammatory activity of 6-MC and its mechanisms and observed that 6-MC attenuates inflammation via the MAPK and NF- $\mathrm{KB}$ signaling pathway-dependent inflammation-mediated factors and pro-inflammatory cytokines downregulation in RAW 264.7 cells.

To determine the effect of 6-MC on inflammation, NO, PGE 2 , TNF- $\alpha$, IL-6, and IL$1 \beta$ levels were measured using Griess reagent and an ELISA kit. The results showed that the levels of inflammation-related cytokines and mediators were reduced by 6-MC treatment in a concentration-dependent manner (Figures 2 and 4). In addition, to confirm whether $\mathrm{NO}$ and $\mathrm{PGE}_{2}$ levels were regulated by iNOS and COX-2 expression, a Western blot assay was performed to measure protein expression levels. As a result, protein expression was markedly induced by LPS treatment, but was significantly attenuated by 6-MC treatment in a dose-dependent manner (Figure 5). Based on this result, 6-MC reduced inflammation-mediated factors via downregulation of iNOS and COX-2 protein expression. To confirm whether 6-MC is related to the MAPK and NF- $\mathrm{kB}$ pathways, which are inflammation-related signaling pathways, a Western blot experiment was performed. It has been reported that the phosphorylation of MAPK (ERK, JNK, and p38) is closely associated with the expression of inflammatory cytokines. ERK in the ERK signaling pathway is phosphorylated by various stimulating factors, whereas p38 and JNK constitute a stress response pathway and are phosphorylated by cellular stress induced by factors such as inflammatory cytokines [11-13]. The result showed that phosphorylation of the MAPK family (ERK, JNK, p38) was reduced by 6-MC treatment (Figure 6). Therefore, 6-MC suppresses the MAPK signaling pathway by inhibiting phosphorylation of the MAPK family. A previous study has reported that in LPS-stimulated RAW 264.7 cells, IKB- $\alpha$ is phosphorylated and released from the NF- $\mathrm{kB}$ complex; consequently, NF- $\mathrm{kB}$ (p50 and p65) is translocated from the cytoplasm to the nucleus, upregulating the production of inflammatory cytokines [45]. In our study, LPS treatment decreased I $\kappa$ B- $\alpha$ expression, which was significantly increased by 6-MC treatment. Additionally, phosphorylation of I $\mathrm{KB}-\alpha$ was induced by LPS treatment, whereas it was significantly decreased by 6-MC treatment in a dose-dependent manner (Figure 7). Moreover, the cells treated with 6-MC were significantly protected from the inhibition of p65 expression in the cytoplasm, and the expression of p65 was decreased by 6-MC treatment in the nucleus (Figure 8). These results suggest that 6-MC suppresses the activity of the NF- $\mathrm{kB}$ signaling pathway by inhibiting the degradation of I $\mathrm{KB}-\alpha$ in the cytoplasm and preventing NF- $\mathrm{kB}$ translocation to the nucleus. The results of mechanistic studies suggest that 6-MC inhibits inflammatory cytokine expression by downregulating the MAPK and NF- $\mathrm{KB}$ signaling pathways.

In summary, this study is the first to evaluate the inhibitory effect of 6-MC on inflammation in RAW 264.7 macrophages. Moreover, 6-MC was shown to exert anti-inflammatory effects in cells by inhibiting the production of inflammatory mediators and pro-inflammatory cytokines via the inhibition of MAPK phosphorylation and protection of IкB- $\alpha$ degradation in the cells treated with LPS (Figure 9). These findings suggest that 6-MC is a potential therapeutic agent for inflammatory diseases, such as dermatitis, arthritis, cardiovascular disease, and cancer. 


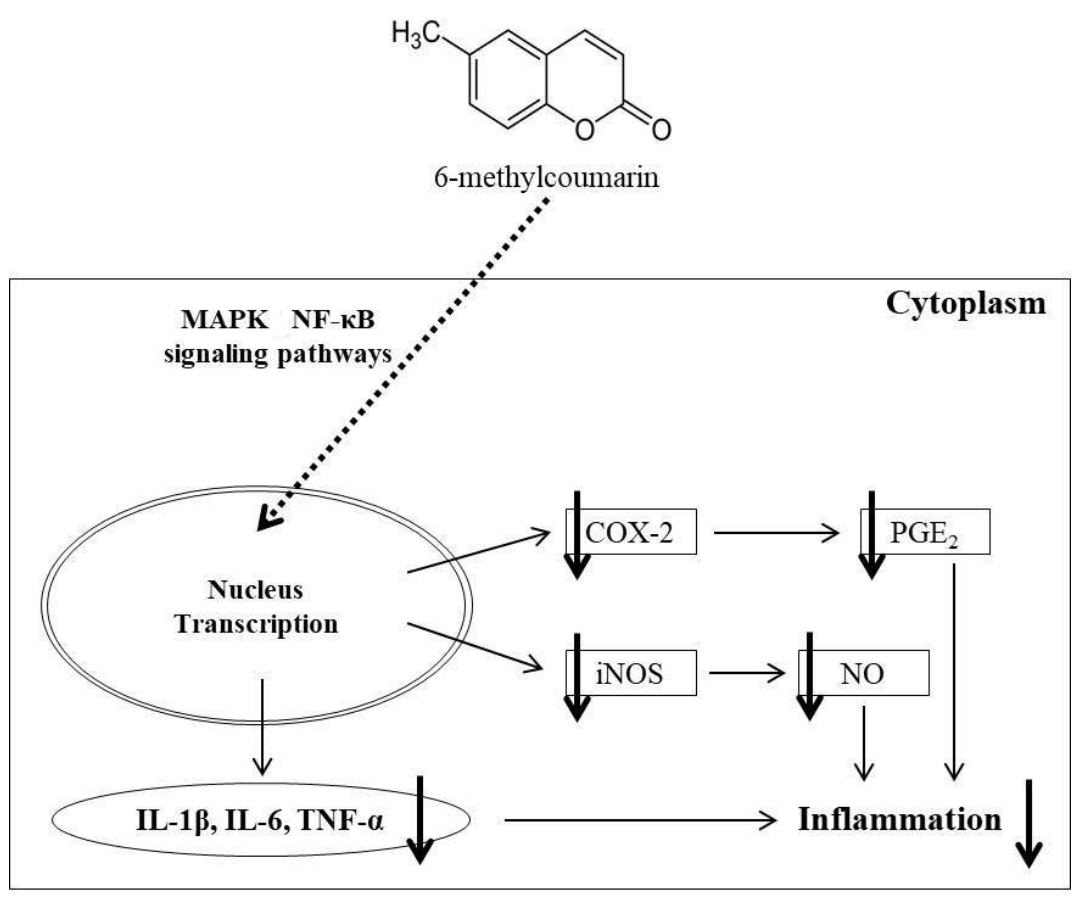

Figure 9. 6-MC induces anti-inflammatory effects by inhibiting the production of inflammatory mediators (NO and PGE 2 ) and pro-inflammatory cytokines (IL-1 $\beta$, IL- 6 , and TNF- $\alpha$ ) via MAPK and NF- $\mathrm{kB}$ signaling pathways in the cells treated with LPS.

\section{Materials and Methods}

\subsection{Chemicals and Reagents}

6-Methylcoumarin (6-MC), 7-methylcoumarin (7-MC), 4-hydroxy-6-methylcoumarin (4H-6-MC), 4-hydroxy-7-methylcoumarin (4H-7-MC), dimethyl sulfoxide (DMSO), radioimmunoprecipitation assay (RIPA) buffer, Griess reagent, sodium nitrite, protease inhibitor cocktail, and phosphate buffered saline (PBS) were obtained from Sigma-Aldrich (St. Louis, MO, USA). Lipopolysaccharides derived from Escherichia coli (LPS) and 3-(4,5dimethylthiazol-2-yl)-2,5-diphenyltetrazolium bromide (MTT) were obtained from VWR (Radnor, PA, USA). Dulbecco's modified Eagle's medium (DMEM), fetal bovine serum (FBS), penicillin/streptomycin, and nuclear and cytoplasmic extraction reagents (NCER) were obtained from Thermo Fisher Scientific (Waltham, MA, USA). Tris-buffered saline (TBS) and enhanced chemiluminescence (ECL) kits were obtained from Biosesang (Seongnam, Gyeonggi-do, Korea). The following antibodies were used: $\beta$-actin, anti-iNOS, anti-COX-2, T-IкB $\alpha, \mathrm{p}-\mathrm{I} \kappa \mathrm{B} \alpha$, T-ERK, p-pERK, T-JNK, p-JNK, T-p38, and p-p38. They were obtained from BD Biosciences (San Diego, CA, USA). The interleukin-6 (IL-6), interleukin$1 \beta$ (IL-1 $\beta)$, prostaglandin $\mathrm{E}_{2}\left(\mathrm{PGE}_{2}\right)$, and tumor necrosis factor (TNF- $\left.\alpha\right)$ ELISA kits were obtained from R\&D Systems Inc. (St, Louis, MO, USA). The protein levels were quantified and graphed using the ImageJ program (NIH, Bethesda, MD, USA). All reagents used above were of analytical grade.

\subsection{Cell Culture}

RAW 264.7 mouse macrophage cells were obtained from the Korean Cell Bank (Seoul, Korea). B16F10 mouse melanoma cells were purchased from the Global BioResource Center (ATCC). RAW 264.7 and B16F10 cells were subcultured at intervals of 2 and 4 days, respectively, using DMEM containing $10 \%$ FBS and 1\% penicillin/streptomycin. The cells were maintained in $5 \% \mathrm{CO}_{2}$ at $37^{\circ} \mathrm{C}$. 


\subsection{Measurement of Cell Viability}

Cell viability was determined using the MTT assay. RAW 264.7 murine macrophage cells were cultured at $1.5 \times 10^{5}$ cells/well in 24 -well plates for $24 \mathrm{~h}$. The cells were then treated with various concentrations of 6-MC $(200,300,400$, and $500 \mu \mathrm{M})$ for $24 \mathrm{~h}$. B16F10 cells were cultured at $1.5 \times 10^{4}$ cells/well in 24 -well plates for $24 \mathrm{~h}$. After that, the cells were treated with various concentrations of $6-\mathrm{MC}(50,100,150,200,250$, and $300 \mu \mathrm{M})$ for $72 \mathrm{~h}$. Next, MTT solution $(0.2 \mathrm{mg} / \mathrm{mL})$ was added to the medium for $4 \mathrm{~h}$, the medium was removed, and the formazan crystals in each well were dissolved in DMSO to determine cell viability. Absorbance was measured at $570 \mathrm{~nm}$ with a spectrophotometer, and the percentage of cells exhibiting cell viability compared to the control was determined.

\subsection{Measurement of NO Production}

The NO production accumulated in the cell culture was measured in the form of nitrite using Griess reagent. RAW 264.7 mouse cells were plated at $1.5 \times 10^{5}$ cells/well in 24 -well plates. The cells were pretreated with various concentrations of samples $(200,300$, 400 , and $500 \mu \mathrm{M})$ for $1 \mathrm{~h}$, and then treated with LPS $(1 \mu \mathrm{g} / \mathrm{mL})$ for $24 \mathrm{~h}$. Thereafter, the cell supernatant and Griess reagent were mixed in a $100 \mu \mathrm{L}$ reaction mixture $(50 \mu \mathrm{L}$ of cell supernatant and $50 \mu \mathrm{L}$ of Griess reagent) for $20 \mathrm{~min}$. Absorbance was measured at $540 \mathrm{~nm}$ using a spectrophotometer. A standard curve was created using sodium nitrite to quantify the amount of NO produced in the sample.

\subsection{Measurement of Intracellular Melanin Content}

B16F10 melanoma cells were seeded in a $60 \mathrm{~mm}$ dish at $6.0 \times 10^{4}$ cells/dish and incubated for $24 \mathrm{~h}$. The cells were then treated with coumarin derivatives $(100,150,200$, and $250 \mu \mathrm{M})$ and $\alpha$-MSH $(100 \mathrm{nM})$ for $72 \mathrm{~h}$. $\alpha$-MSH served as the positive control. After the supernatant was removed, the cells were washed twice with phosphate buffered saline (PBS), and the cell pellets were collected and dissolved in $1 \mathrm{~N} \mathrm{NaOH}$ for $1 \mathrm{~h}$ at $70{ }^{\circ} \mathrm{C}$. Each cell lysate was transferred to a 96-well plate, and the absorbance of each well was determined at $540 \mathrm{~nm}$ using a spectrophotometer.

\subsection{Measurement of Cytokines}

RAW 264.7 mouse cells were plated at $1.5 \times 10^{5}$ cells/well in 24-well plates. The cells were pretreated with various concentrations of samples $(200,300,400$, and $500 \mu \mathrm{M})$ for $1 \mathrm{~h}$, and then treated with LPS $(1 \mu \mathrm{g} / \mathrm{mL})$ for $24 \mathrm{~h}$. Supernatants were harvested, and the levels of PGE 2 and pro-inflammatory cytokines IL- 6, IL- $1 \beta$, and TNF- $\alpha$ were measured using ELISA kits according to the manufacturer's protocol.

\subsection{Preparation of Nuclear and Cytosolic Extraction}

Nuclear and cytosolic extracts were fractionated using a previously reported procedure [49]. Briefly, after washing once with PBS, the cells were harvested using trypsin-EDTA and then centrifuged at $500 \times g$ for $5 \mathrm{~min}$. After that, the pellet was washed with PBS and centrifuged at $500 \times g$ for $3 \mathrm{~min}$, after which the supernatant was removed. After adding $200 \mu \mathrm{L}$ of cytoplasmic extraction reagent (CER) 1 on ice, the mixture was vortexed for $15 \mathrm{~s}$ and allowed to react in a cold state for $10 \mathrm{~min}$. After adding $11 \mu \mathrm{L}$ of cytoplasmic extraction reagent (CER) 2 on ice, the mixture was vortexed for $5 \mathrm{~s}$ and allowed to react in a cold state for $1 \mathrm{~min}$. After vortexing for $5 \mathrm{~s}$, centrifugation was performed at $16,000 \times g$ for $5 \mathrm{~min}$. The supernatant was stored in an e-tube and used as a cytoplasmic protein. After adding $100 \mu \mathrm{L}$ of nuclear extraction reagent (NER) to the remaining pellet on ice, it was vortexed for $15 \mathrm{~s}$ and reacted in a cold state for $10 \mathrm{~min}$. This process was repeated four times. The samples were centrifuged at $16,000 \times g$ for $10 \mathrm{~min}$, and the supernatant was transferred to an e-tube and used as a nuclear protein. The separated proteins were stored at $-80^{\circ} \mathrm{C}$. 


\subsection{Western Blot Analysis}

RAW 264.7 mouse cells were plated at a density of $7.0 \times 10^{5}$ cells $/$ dish in a $60-\mathrm{mm}$ cell culture dish for $24 \mathrm{~h}$. Cells were pretreated with various concentrations of 6-MC $(200,300$, $400,500 \mu \mathrm{M})$ for $1 \mathrm{~h}$, treated with LPS $(1 \mu \mathrm{g} / \mathrm{mL})$ for the specified time with cold $1 \times$ PBS, and washed twice. After lysis for $20 \mathrm{~min}$ in RIPA lysis buffer $(150 \mathrm{mM} \mathrm{NaCl}, 50 \mathrm{mM}$ Tris- $\mathrm{HCl}$ [pH 7.5], $2 \mathrm{mM}$ EDTA, $1 \%$ Triton X-100, 0.1\% SDS, 10\% NP40, and 1\% protein inhibitor cocktail), the lysate was transferred to a microtube and centrifuged at $-8{ }^{\circ} \mathrm{C}$ and $15,000 \mathrm{rpm}$ for $20 \mathrm{~min}$. A protein was obtained from a cell lysate extracted using the BCA Protein Assay Kit, which is a standard calibration curve for bovine serum albumin (BSA). The content was calculated quantitatively. Whole-cell lysates $(20 \mu \mathrm{g})$ were separated by SDS-polyacrylamide gel electrophoresis on a 10\% gel (SDS-PAGE) and electro-transferred to polyvinylidene fluoride (PVDF) membranes. The membranes were incubated for $2 \mathrm{~h}$ with $5 \%$ skim milk. Next, the membrane was incubated for $8 \mathrm{~h}$ with specific primary antibodies (1:2000). The membrane was washed six times with TTBS buffer every $10 \mathrm{~min}$ and incubated for $2 \mathrm{~h}$ at $27^{\circ} \mathrm{C}$ with a peroxidase-conjugated secondary antibody (1:1000). Finally, the membrane was washed six times with TTBS buffer every $10 \mathrm{~min}$, and the proteins were detected using an ECL kit.

\subsection{Data Analysis}

All experimental results are expressed as the mean \pm standard deviation of three independent experiments. Statistical analysis was performed using the Student's $t$-test. $p$-values $<0.05\left(^{*}\right)$ or $0.01\left(^{* *}\right)$ were considered statistically significant.

Author Contributions: All authors contributed significantly to this project. J.-K.K. and C.-G.H. designed the research; J.-K.K. performed the research; J.-K.K., Y.-C.C. and C.-G.H. analyzed the data; Y.-C.C. and C.-G.H. wrote the paper; and Y.-C.C. and C.-G.H. reviewed and edited the paper. All authors have read and agreed to the published version of the manuscript.

Funding: This research was supported by the 2021 scientific promotion program funded by Jeju National University.

Institutional Review Board Statement: Not applicable.

Informed Consent Statement: Not applicable.

Data Availability Statement: Not applicable.

Acknowledgments: This research was supported by the Ministry of Trade, Industry \& Energy (MOTIE), Korea Institute for Advancement of Technology (KIAT) through the Construction Project for Skin Clinical Solution Center (P0017663).

Conflicts of Interest: The authors declare no conflict of interest.

Sample Availability: Samples of the compounds are available from the authors.

\section{References}

1. Barning, C.; Bezema, T.; Calder, P.C.; Charloux, A.; Frossard, N.; Garssen, J.; Haworth, O.; Dilevskaya, K.; Levi-Schaffer, F.; Lonsdorfer, E.; et al. Activation of Resolution Pathways to Prevent and Fight Chronic Inflammation: Lessons From Asthma and Inflammatory Bowel Disease. Front. Immunol. 2019, 10, 1699. [CrossRef]

2. Ward, P.A.; Lentsch, A.B. The Acute Inflammatory Response and Its Regulation. Arch. Surg. 1999, 134, 666-669. [CrossRef]

3. Medzhitov, R. Inflammation 2010: New adventures of an old flame. Cell 2010, 140, 771-776. [CrossRef]

4. Ferrero-Miliani, L.; Nielsen, O.H.; Andersen, P.S.; Girardin, S.E. Chronic inflammation: Importance of NOD2 and NALP3 in interleukin-1beta generation. Clin. Exp. Immunol. 2007, 147, 227-235. [CrossRef]

5. Nathan, C.; Ding, A. Nonresolving inflammation. Cell 2010, 140, 871-882. [CrossRef]

6. Zhou, Y.; Hong, Y.; Huang, H. Triptolide Attenuates Inflammatory Response in Membranous Glomerulo-Nephritis Rat via Downregulation of NF-кB Signaling Pathway. Kidney. Blood. Press. Res. 2016, 41, 901-910. [CrossRef] [PubMed]

7. Takeuchi, O.; Akira, S. Pattern recognition receptors and inflammation. Cell 2010, 140, 805-820. [CrossRef]

8. Frostegård, J.; Ulfgren, A.K.; Nyberg, P.; Hedin, U.; Swedenborg, J.; Andersson, U.; Hansson, G.K. Cytokine expression in advanced human atherosclerotic plaques: Dominance of pro-inflammatory (Th1) and macrophage-stimulating cytokines. Atherosclerosis 1999, 145, 33-43. [CrossRef] 
9. Matthay, M.A.; Zimmerman, G.A.; Esmon, C.; Bhattacharya, J.; Coller, B.; Doerschuk, C.M.; Floros, J.; Gimbrone Jr, M.A.; Hoffman, E.; Hubmayr, R.D.; et al. Future research directions in acute lung injury: Summary of a National Heart, Lung, and Blood Institute working group. Am. J. Respir. Crit. Care Med. 2003, 167, 1027-1035. [CrossRef] [PubMed]

10. Reibman, J.; Talbot, A.T.; Hsu, Y.; Ou, G.; Jover, J.; Nilsen, D.; Pillinger, M.H. Regulation of expression of granulocyte-macrophage colony-stimulating factor in human bronchial epithelial cells: Roles of protein kinase $\mathrm{C}$ and mitogen activated protein kinases. J. Immunol. 2000, 165, 1618-1625. [CrossRef] [PubMed]

11. Kaminska, B. MAPK signalling pathways as molecular targets for antiinflammatory therapy from molecular mechanisms to therapeutic benefits. Biochim. Biophys. Acta. 2005, 1754, 253-262. [CrossRef]

12. Carter, A.B.; Knudtson, K.L.; Monick, M.M.; Hunninghake, G.W. The p38 mitogen-activated protein kinase is required for NF-kappaB-dependent gene expression. The role of TATA-binding protein (TBP). J. Biol. Chem. 1999, 274, 30858-30863. [CrossRef] [PubMed]

13. Nakano, H.; Shindo, M.; Sakon, S.; Nishinaka, S.; Mihara, M.; Yagita, H.; Okumura, K. Differential regulation of IkappaB kinase alpha and beta by two upstream kinases, NF-kappaB-inducing kinase and mitogen-activated protein kinase/ERK kinase kinase-1. Proc. Natl. Acad. Sci. USA 1998, 95, 3537-3542. [CrossRef] [PubMed]

14. Shin, J.S.; Kim, J.M.; An, W.G. Anti-inflammatory Effect of Red Ginseng through Regulation of MAPK in Lipopolysaccharidestimulated RAW264. Korean J. Orient. Physiol. Pathol. 2012, 26, 293-300.

15. Paik, Y.H.; Schwabe, R.F.; Bataller, R.; Russo, M.P.; Jobin, C.; Brenner, D.A. Toll-like receptor 4 mediates inflammatory signaling by bacterial lipopolysaccharide in human hepatic stellate cells. Hepatology 2003, 37, 1043-1055. [CrossRef]

16. Suzuki, H.; Chiba, T.; Kobayashi, M.; Takeuchi, M.; Furuichi, K.; Tanaka, K. In vivo and in vitro recruitment of an IkappaBalphaubiquitin ligase to IkappaBalpha phosphorylated by IKK, leading to ubiquitination. Biochem. Biophys. Res. Commun. 1999, 256, 121-126. [CrossRef]

17. Guha, M.; Mackman, N. LPS induction of gene expression in human monocytes. Cell. Signal. 2001, 13, 85-94. [CrossRef]

18. Ghosh, S.; Hayden, H.S. New regulators of NF-кB in inflammation. Nat. Rev. Immunol. 2008, 8, 837-848. [CrossRef]

19. Majdalawieh, A.; Ro, H.S. Regulation of $\mathrm{I} \kappa \mathrm{B} \alpha$ function and NF- $\mathrm{kB}$ signaling: AEBP1 is a novel proinflammatory mediator in macrophages. Mediat. Inflamm. 2010, 2010, 821-823. [CrossRef]

20. Park, S.M.; Byun, S.H.; Kim, Y.W.; Cho, I.J.; Kim, S.C. Inhibitory effect of Mori Folium ethanol extract on pro-inflammatory mediator in lipopolysaccharide activated RAW 264.7 cells. Korean J. Herbol. 2012, 27, 31-38. [CrossRef]

21. He, G.; Karin, M. NF-кB and STAT3-key players in liver inflammation and cancer. Cell Res. 2011, 21, 159-168. [CrossRef]

22. Jalava, P.I.; Salonen, R.O.; Pennanen, A.S.; Sillanpää, M.; Hälinen, A.I.; Happo, M.S.; Hillamo, R.; Brunekreef, B.; Katsouyanni, K.; Sunyer, J.; et al. Heterogeneities in inflammatory and cytotoxic responses of RAW 264.7 macrophage cell line to urban air coarse, fine, and ultrafine particles from six European sampling campaigns. Inhal. Toxicol. 2007, 19, 213-225. [CrossRef]

23. Manzi, S.; Wasko, M.C. Inflammation-mediated rheumatic diseases and atherosclerosis. Ann. Rheum. Dis. 2000, 59, 321-325. [CrossRef]

24. Abramson, S.B.; Amin, A.R.; Clancy, R.M.; Attur, M. The role of nitric oxide in tissue destruction. Best Pract. Res. Clin. Rheumatol. 2001, 15, 831-845. [CrossRef]

25. Glezeva, N.; Baugh, J.A. Role of inflammation in the pathogenesis of heart failure with preserved ejection fraction and its potential as a therapeutic target. Heart Fail. Rev. 2014, 19, 681-694. [CrossRef]

26. Manohar, M.; Verma, A.K.; Venkateshaiah, S.U.; Sanders, N.L.; Mishra, A. Pathogenic mechanisms of pancreatitis. World J. Gastrointest. Pharmacol. Ther. 2017, 8, 10-25. [CrossRef]

27. Brenner, C.; Galluzzi, L.; Kepp, O.; Kroemer, G. Decoding cell death signals in liver inflammation. J. Hepatol. 2013, 59, 583-594. [CrossRef]

28. Walford, H.H.; Doherty, T.A. STAT6 and lung inflammation. JAKSTAT 2013, 2, e25301. [CrossRef] [PubMed]

29. Ekdahl, C.T.; Claasen, J.H.; Bonde, S.; Kokaia, Z.; Lindvall, O. Inflammation is detrimental for neurogenesis in adult brain. Proc. Natl. Acad. Sci. USA 2003, 100, 13632-13637. [CrossRef]

30. Kostova, I.; Raleva, S.; Genova, P.; Argirova, R. Structure-activity relationships of synthetic coumarins as HIV-1 inhibitors. Bioinorg. Chem. Appl. 2006, 2006, 68274. [CrossRef] [PubMed]

31. Pereira, T.M.; Franco, D.F.; Vitorio, F.; Kummerle, A.E. Coumarin compounds in medicinal chemistry: Some important examples from the last years. Curr. Top. Med. Chem. 2018, 18, 124-148. [CrossRef]

32. Stefanachi, A.; Leonetti, F.; Pisani, L.; Catto, M.; Carotti, A. Coumarin: A natural, privileged and versatile scaffold for bioactive compounds. Molecules 2018, 23, 250. [CrossRef]

33. Annunziata, F.; Pinna, C.; Dallavalle, S.; Tamborini, L.; Pinto, A. An overview of coumarin as a versatile and readily accessible scaffold with broad-ranging biological activities. Int. J. Mol. Sci. 2020, 21, 4618. [CrossRef]

34. Hoult, J.R.S.; Payá, M. Pharmacological and biochemical actions of simple coumarins: Natural products with therapeutic potential. Gen. Pharmacol. 1996, 27, 713-722. [CrossRef]

35. Zhu, J.J.; Jiang, J.G. Pharmacological and nutritional effects of natural coumarins and their structure-activity relationships. Mol. Nutr. Food Res. 2017, 62, e1701073. [CrossRef]

36. Kang, Y.S.; Chung, Y.C.; Lee, J.N.; Kim, B.S.; Hyun, C.-G. Anti-Inflammatory Effects of 6,7-Dihydroxy-4-Methylcoumarin on LPS-Stimulated Macrophage Phosphorylation in MAPK Signaling Pathways. Nat. Prod. Commun. 2021, 16, 1-8. [CrossRef] 
37. Lee, N.; Chung, Y.C.; Kang, C.I.; Park, S.-M.; Hyun, C.-G. 7,8-dimethoxycoumarin attenuates the expression of IL-6, IL-8, and CCL2/MCP-1 in TNF- $\alpha$-treated HaCaT cells by potentially targeting the NF-kB and MAPK pathways. Cosmetics $2019,6,41$. [CrossRef]

38. Chung, Y.C.; Kim, S.Y.; Hyun, C.-G. 8-Methoxycoumarin enhances melanogenesis via the mapkase signaling pathway. Pharmazie 2019, 74, 529-535. [CrossRef]

39. Chung, Y.C.; Park, S.-M.; Kim, J.H.; Lee, G.S.; Lee, J.N.; Hyun, C.-G. Anti-inflammatory Effect of Pratol in LPS-stimulated RAW 264.7 Cells via NF-кB Signaling Pathways. Nat. Prod. Commun. 2018, 13, 547-550. [CrossRef]

40. Chung, Y.C.; Kim, S.; Kim, J.H.; Lee, G.S.; Lee, J.N.; Lee, N.H.; Hyun, C.-G. Pratol, an O-Methylated Flavone, Induces Melanogenesis in B16F10 Melanoma Cells via p-p38 and p-JNK Upregulation. Molecules 2017, 22, 1704. [CrossRef]

41. Lee, N.; Chung, Y.C.; Kim, Y.B.; Park, S.M.; Kim, B.S.; Hyun, C.-G. 7,8-Dimethoxycoumarin stimulates melanogenesis via MAPKs mediated MITF upregulation. Pharmazie 2020, 75, 107-111. [CrossRef] [PubMed]

42. Sahu, D.; Raghav, S.K.; Gautam, H.; Das, H.R. A novel coumarin derivative, 8-methoxychromen-2-one alleviates collagen induced arthritis by down regulating nitric oxide, $\mathrm{NFKB}$ and proinflammatory cytokines. Int. Immunopharmacol. 2015, 29, 891-900. [CrossRef]

43. Guzik, T.J.; Korbut, R.; Adamek-Guzik, T. Nitric oxide and superoxide in inflammation and immune regulation. J. Physiol. Pharmacol. 2003, 54, 469-487. [PubMed]

44. Barnes, P.J.; Liew, F.Y. Nitric oxide and asthmatic inflammation. Immunol. Today. 1995, 16, 128-130. [CrossRef]

45. Lawrence, T. The nuclear factor NF-кB pathway in inflammation. Cold Spring Harb. Perspect. Biol. 2009, 1, a001651. [CrossRef]

46. Lin, S.; Hirai, S.; Goto, T.; Sakamoto, T.; Takahashi, N.; Yano, M.; Sasaki, T.; Yu, R.; Kawada, T. Auraptene suppresses inflammatory responses in activated RAW264 macrophages by inhibiting p38 mitogen-activated protein kinase activation. Mol. Nutr. Food Res. 2013, 57, 1135-1144. [CrossRef]

47. Niu, X.; Wang, Y.; Li, W.; Zhang, H.; Wang, X.; Mu, Q.; He, Z.; Yao, H. Esculin exhibited anti-inflammatory activities in vivo and regulated TNF- $\alpha$ and IL-6 production in LPS-stimulated mouse peritoneal macrophages in vitro through MAPK pathway. Int. Immunopharmacol. 2015, 29, 779-786. [CrossRef]

48. Kang, J.K.; Hyun, C.-G. 4-Hydroxy-7-Methoxycoumarin Inhibits Inflammation in LPS-activated RAW264.7 Macrophages by Suppressing NF-KB and MAPK Activation. Molecules 2020, 25, 4424. [CrossRef]

49. Jeon, H.L.; Yoo, J.M.; Lee, B.D.; Lee, S.J.; Sohn, E.J.; Kim, M.R. Anti-inflammatory and antioxidant actions of N-arachidonoyl serotonin in RAW264.7 cells. Pharmacology 2016, 97, 195-206. [CrossRef] 